\title{
OCCURRENCE OF PLANT GROWTH-PROMOTING TRAITS IN CLOVER-NODULATING RHIZOBIA STRAINS ISOLATED FROM DIFFERENT SOILS IN RIO GRANDE DO SUL STATE ${ }^{(1)}$
}

\author{
Luciano Kayser $\operatorname{Vargas}^{(2)}$, Bruno Brito Lisboa ${ }^{(2)}$, Gilson \\ Schlindwein ${ }^{(2)}$, Camille Eichelberger Granada ${ }^{(2)}, \operatorname{Adriana~Giongo~}^{(3)}$, \\ Anelise Beneduzi ${ }^{(3)}$ \& Luciane Maria Pereira Passaglia ${ }^{(3)}$
}

\begin{abstract}
SUMMARY
In the last decades, the use of plant growth-promoting rhizobacteria has become an alternative to improve crop production. Rhizobium leguminosarum biovar trifolii is one of the most promising rhizobacteria and is even used with nonlegume plants. This study investigated in vitro the occurrence of plant growthpromoting characteristics in several indigenous $R$. leguminosarum biovar trifolii isolated from soils in the State of Rio Grande do Sul, Brazil. Isolates were obtained at 11 locations and evaluated for indoleacetic acid and siderophore production and inorganic phosphate solubilization. Ten isolates were also molecularly characterized and tested for antagonism against a phytopathogenic fungus and for plant growth promotion of rice seedlings. Of a total of 252 isolates, 59 produced indoleacetic acid, 20 produced siderophores and 107 solubilized phosphate. Some degree of antagonism against Verticillium $\mathrm{sp.} \mathrm{was} \mathrm{observed} \mathrm{in} \mathrm{all} \mathrm{tested} \mathrm{isolates,}$ reducing mycelial growth in culture broth. Isolate AGR-3 stood out for increasing root length of rice seedlings, while isolate ELD-18, besides increasing root length in comparison to the uninoculated control, also increased the germination speed index, shoot length, and seedling dry weight. These results confirm the potential of some strains of $R$. leguminosarum biovar trifolii as plant growth-promoting rhizobacteria.
\end{abstract}

Index terms: rhizobacteria, siderophore, indoleacetic acid, phosphate solubilization, antagonism, rice.

\footnotetext{
(1) Trabalho realizado com o apoio financeiro da IFS e da FAPERGS. Recebido para publicação em dezembro de 2008 e aprovado em maio de 2009.

(2) Pesquisador da FEPAGRO. Rua Gonçalves Dias 570, CEP 90130-060 Porto Alegre (RS). E-mail: luciano@fepagro.rs.gov.br

${ }^{(3)}$ Professora do Departamento de Genética, Universidade Federal do Rio Grande do Sul - UFRGS. Av. Bento Gonçalves 7712, CEP 91540-000 Porto Alegre (RS). E-mail: lpassaglia@terra.com.br
} 


\title{
RESUMO: OCORRÊNCIA DE CARACTERÍSTICAS DE PROMOÇÃO DE CRESCIMENTO EM RIZÓBIOS NODULADORES DE TREVO ISOLADOS DE SOLOS DO RIO GRANDE DO SUL
}

\begin{abstract}
Nas últimas décadas, o uso de rizobactérias promotoras de crescimento de plantas tem se mostrado uma alternativa para aumentar a produção vegetal. Rhizobium leguminosarum biovar trifolii está entre as mais promissoras rizobactérias e tem sido usada também em não leguminosas. O presente trabalho analisou in vitro a ocorrência de características de promoção de crescimento vegetal em isolados de R. leguminosarum biovar trifolii nativos de solos do Rio Grande do Sul. Os isolados foram obtidos de 11 localidades e avaliados quanto à produção de ácido indolacético, produção de sideróforos e solubilização de fosfato. Dez isolados foram também caracterizados molecularmente e testados com relação a antagonismo a um fungo fitopatogênico e promoção de crescimento em plântulas de arroz. De um total de 252 isolados, 59 produziram ácido indolacético, 20 produziram sideróforos e 107 solubilizaram fosfato. Todos os isolados apresentaram algum grau de antagonismo a Verticillium sp., reduzindo o crescimento micelial em meio líquido. O isolado AGR-3 destacou-se por aumentar o crescimento radicular das plântulas de arroz, enquanto o isolado ELD-18, além de aumentar o comprimento das raízes em comparação com o controle não inoculado, também aumentou o índice de velocidade de germinação, o comprimento da parte aérea e a massa das plântulas secas. Esses resultados confirmam o potencial de $\mathrm{R}$. leguminosarum biovar trifolii como rizobactéria promotora de crescimento de plantas.
\end{abstract}

Termos de indexação: rizobactéria, ácido indolacético, solubilização de fosfato, antagonismo, arroz.

\section{INTRODUCTION}

Inoculation of plants with beneficial bacteria is a practice that can be traced back for centuries. Farmers have long known from experience that when they mixed soil taken from a previous legume crop with soil in which non-legumes were grown, crop yields often improved. By the end of the $19^{\text {th }}$ century, the practice of mixing "naturally inoculated" soil with seeds became a recommended procedure for legume inoculation in the USA (Bashan, 1998). Inoculation of legumes with rhizobia and the use of mycorrhiza in seedlings of different species are the most remarkable examples. Nevertheless, in the last decades, other microorganisms have attracted the attention of researchers with a view to a potential use in agriculture (Kloepper et al., 1980; Ahmad et al., 2008).

Rhizosphere bacteria that are able to increase the productivity of some crops by colonizing roots and stimulating plant growth are known as plant growthpromoting rhizobacteria (PGPR). PGPR activity has been reported for strains belonging to several genera such as Azoarcus, Azospirillum, Azotobacter, Arthrobacter, Bacillus, Clostridium, Enterobacter, Gluconacetobacter, Pseudomonas, and Serratia (Somers \& Vanderleyden, 2004). Even some Rhizobium strains are considered PGPR, since they can promote the growth of non-legumes such as gramineae and cruciferae following root colonization. The growth promotion of non-legume plants by rhizobia has been related to mechanisms that are independent of biological $\mathrm{N}_{2}$ fixation, since neither root nodules nor $\mathrm{N}_{2}$ fixation were observed during these interactions (Somers \& Vanderleyden, 2004).

The response to PGPR inoculation in different crops has been reported in lettuce (Sottero et al., 2006), citrus trees (Freitas \& Vildoso, 2004), potato (Kloepper et al., 1980), canola (Bertrand et al., 2001), red peppers (Joo et al., 2005), and soybean (García et al., 2004). PGPR stimulate plant growth directly either by synthesizing phytohormones or by promoting nutrition processes as phosphate solubilization for example, or even by accelerating the mineralization processes. They can also stimulate growth indirectly by protecting the plant against soil-borne fungal pathogens or deleterious bacteria, by competing with them for iron through their siderophores, and by producing antibiotics and/or chitinases and glucanases, which in turn promote the lyses of microbial cells (Somers \& Vanderleyden, 2004). Many PGPR strains as well as some activators promote legume nodulation and $\mathrm{N}_{2}$ fixation in association with rhizobia. Due to these characteristics, they have been added to rhizobial inoculants (Gray \& Smith, 2005).

In contrast to the symbiotic $\mathrm{N}_{2}$ fixation process, rhizobia PGPR activities are not restricted to the legume host plant. Thus, PGPR rhizobia may be inoculated in several plant species, including nonlegumes. Besides the utilization of $\mathrm{N}$ fixed by rhizobialegume symbiosis, non-legume plants, when associated with or grown in succession to legume, may also take advantage of the rhizobia PGPR activities. The establishment of plant growth promotion by 
rhizobia strains has been observed in crops such as wheat (Hilali et al., 2001), rice (Yanni et al., 2001), canola (Noel et al., 1996), corn (Yanni et al., 2001), lettuce (Noel et al., 1996), and sunflower (Alami et al., 2000).

Rhizobium leguminosarum is one of the most studied PGPR rhizobia. R. leguminosarum biovar trifolii, related to clover nodulation, has shown great potential as PGPR (Biswas et al., 2000a,b; Hilali et al., 2001; Yanni et al., 2001). This study intended to investigate in vitro the presence of plant growthpromoting features in several indigenous $R$. leguminosarum biovar trifolii isolated from soils of Rio Grande do Sul State, Brazil, as well as test the PGPR activities of some selected isolates in rice plants.

\section{MATERIAL AND METHODS}

\section{Sampling and rhizobia isolation}

Samples of white clover (Trifolium repens) or arrow leaf clover ( $T$. vesiculosum) roots were collected from 11 different areas in Rio Grande do Sul State, Brazil: Porto Alegre (AGR), Eldorado do Sul (ELD), Cachoeirinha (IRG), Caxias do Sul (CXS), São Borja (SBO), Vacaria (VAC), São Gabriel (SGA), Dom Pedrito (DPE), Rio Grande (RIG), Rio Pardo (RIP) and Uruguaiana (URU). Fresh root nodules were collected from 20 plants at each sampling site, and maintained on silica gel. The nodules were randomly excised and surface-sterilized with ethanol and hydrogen peroxide. Rhizobia were isolated on yeast-extract mannitol agar (YEMA) using standard procedures and purified by repeated streaking (Somasegaran \& Hoben, 1994).

All isolates, along with the reference strains SEMIA 222 and SEMIA 235, were tested for indoleacetic acid (IAA) and siderophore production and inorganic phosphate solubilization. The production of indoleacetic acid was evaluated according to Asghar et al. (2002). Briefly, rhizobial strains were grown in yeast-mannitol broth (YMB) (Somasegaran \& Hoben, 1994) supplemented with $50 \mathrm{mg} \mathrm{L}^{-1}$ tryptophan. After $48 \mathrm{~h}$, bacterial cultures were centrifuged at $10.000 \mathrm{rpm}$ for $5 \mathrm{~min}$ and $60 \mu \mathrm{L}$ of the supernatants generated were placed in microplates to react with $40 \mu \mathrm{L}$ Salkowski reagent $\left(2 \mathrm{~mL} 0.5 \mathrm{~mol} \mathrm{~L}^{-1} \mathrm{FeCl}_{3}+\right.$ $\left.98 \mathrm{~mL} 35 \% \mathrm{HClO}_{4}\right)$. The mixture was left in the dark for $30 \mathrm{~min}$ at room temperature. Samples that turned red were considered positive.

For the siderophore production assay, the isolates were grown in iron-deficient King's B medium for $72 \mathrm{~h}$ (Ahmad et al., 2008). At the end of this period, bacterial cultures were centrifuged as described previously. An aliquot of $50 \mu \mathrm{L}$ was collected from each supernatant and pipetted into a microplate along with $50 \mu \mathrm{L}$ of chrome azurol-S (CAS) reagent (Schwyn
\& Neilands, 1987). After $15 \mathrm{~min}$, isolates that changed the color of the reaction mixture from blue to orange were considered positive for siderophore production.

Isolates able to solubilize phosphates were identified by the method described by Sylvester-Bradley et al. (1982). Bacteria were grown in glucose-yeast medium (GY) (Sylvester-Bradley et al., 1982) containing $10 \mathrm{~g}$ glucose, 2 g yeast extract and $15 \mathrm{~g}$ agar per liter. Two other solutions were prepared separately, one containing $5 \mathrm{~g} / 50 \mathrm{~mL} \mathrm{~K}_{2} \mathrm{HPO}_{4}$ in distilled water, and the other containing $10 \mathrm{~g} / 100 \mathrm{~mL} \mathrm{CaCl}_{2}$ in distilled water. These solutions were added to one liter of glucose-yeast (GY) medium immediately before being poured into Petri dishes, forming insoluble calcium phosphate that made the medium opaque. Bacterial isolates previously grown in GY medium were dropped (10 $\mu \mathrm{L}$ per culture) into the GY plates and incubated for seven days at $28^{\circ} \mathrm{C}$. The isolates that formed visible clear halos around their colonies were considered phosphate solubilizers.

Ten isolates (AGR-3, AGR-7, CXS-12, DPE-12, ELD-15, ELD-18, IRG-17, SBO-3, SGA-15 and VAC12) with different PGPR characteristics were selected for further testing. Initially, these isolates and the reference strains (SEMIA 222 and SEMIA 235) were genetically characterized using the enterobacterial repetitive intergenic consensus primers ERIC1-R and ERIC-2 (De Bruijn, 1992) and enterobacterial repetitive sequences (BOX-A1) primer (Versalovic et al., 1994) as molecular markers. The fingerprinting of the two molecular markers was converted into a matrix ( 1 for presence, 0 for absence of the band). A similarity tree was constructed, using software PAST, based on the Jaccard coefficient to estimate similarity among isolates. Hierarchical cluster analysis was performed using the UPGMA (Unweighted Pair Group Mathematical Average) algorithm (Vargas et al., 2007).

Subsequently, the ten selected isolates were tested for antagonism against the soil-borne phytopathogenic fungus Verticillium sp., according to the procedures described by Chao (1990). Isolates were cultured in $50 \mathrm{~mL}$ YM broth for three days. Next, a slice of Verticillium sp. mycelia was added to the medium containing one of the isolates or to an uninoculated control, and left to grow for eight days. Then the broth was filtered through a filter paper with known dry weight. The filter paper containing the retained mycelial mass was dried at $60^{\circ} \mathrm{C}$ to constant weight and re-weighed.

The same ten isolates were also tested for their ability to promote germination vigor and rice seedling growth. Rice seeds were previously surface-sterilized, and a standard germination test was carried out, according to officially recommended procedures (Ista, 1996), with 50 seeds per germination box. In each germination box, the filter paper was soaked with $15 \mathrm{~mL}$ of a $10^{8} \mathrm{cfu} \mathrm{mL}^{-1}$ Rhizobium culture, grown in tryptone-yeast broth (TY) (Somasegaran \& Hoben, 
1994), together with a control treatment, without Rhizobium inoculation. The germination test was conducted for 12 days. The germination speed index, GSI, (Maguire, 1962) and germination percentage after 4, 6 and 10 days, were determined. On the $12^{\text {th }}$ day, the root and shoot length and seedling weight of ten seedlings per germination box were determined. For seedling weight, the caryopses were removed from seedlings and dried at $60{ }^{\circ} \mathrm{C}$ to constant weight.

The experiments were carried out in a completely randomized design, with four replications. The results were submitted to analysis of variance and means compared by the Scott-Knott test at $5 \%$.

\section{RESULTS AND DISCUSSION}

From the 11 sampling sites, a total of 252 rhizobial isolates were obtained, all derived from white clover nodules, with the exception of Rio Pardo (RIP) and Uruguaiana (URU) isolates, derived from nodules of arrow leaf clover. All strains, independent of their origin, had fast growth, the acidic production in YMA contained bromothymol blue, and they did not absorb Congo red dye, which are characteristics of bacteria belonging to the genus Rhizobium.

The isolates were evaluated in relation to indoleacetic acid and siderophore production and phosphate solubilization (Table 1). Positive isolates were found for these three characteristics, confirming the potential of $R$. leguminosarum biovar trifolii as a plant growth-promoting rhizobacteria. However, in only five isolates - ELD-10, ELD-15, CXS-20, RIP-9, and RIP-10 -these three important characteristics were found concomitantly. Besides, in many others two characteristics were observed, such as isolate SBO-3, which produces indoleacetic acid and siderophore; the isolates AGR-3 and ELD-9, producers of siderophore and phosphate solubilizers; and the isolates SBO-7, SBO-16 and ELD-16, indoleacetic acid producers and phosphate solubilizers.

Most isolates with PGPR traits were found at sampling sites in Rio Grande, where at least one of the characteristics was found in 22 isolates, and Eldorado do Sul and Porto Alegre, with 21 isolates at both locations. On the other hand, only one isolate from Vacaria had at least one PGPR trait, the siderophore-producing VAC-13.

In this study, the frequency of each analyzed trait differed strongly from that observed by Antoun et al. (1998). Working with a similar number of isolates of several rhizobia and bradyrhizobia species, these authors found that $58 \%$ of the isolates were IAA producers and $54 \%$ were phosphate solubilizers, while the majority $(83 \%)$ of the isolates produced siderophores. In our study however, we found that siderophore production is a rare trait, found in only $8 \%$ of our isolates. Still, this characteristic was more frequent in isolates from the sampling sites of Eldorado do Sul and Rio Pardo, where $20 \%$ of the rhizobial isolates produced siderophores.

Contrary to siderophore production, phosphate solubilization was the most common characteristic, observed in $42 \%$ of all isolates and in $100 \%$ of the isolates from the sampling site in Porto Alegre and in $68 \%$ of the isolates from Eldorado do Sul. This result confirms the statement of Rodriguez \& Fraga (1999), who considered bacteria belonging to the genus Rhizobium as major phosphate solubilizers, along with bacteria of the genera Pseudomonas and Bacillus.

With regard to the production of indoleacetic acid, a very distinct behavior was observed between rhizobium strains isolated from arrow leaf clover (RIP and URU) and the others, isolated from white clover

Table 1. Number of rhizobial isolates that were indoleacetic acid producers, siderophore producers and phosphate solubilizers per sampling site and the frequency of occurrence of each trait

\begin{tabular}{|c|c|c|c|c|c|c|c|}
\hline \multirow{2}{*}{ Site $^{(1)}$} & \multirow{2}{*}{ No. of isolates } & \multicolumn{2}{|c|}{ Indoleacetic acid } & \multicolumn{2}{|c|}{ Siderophore } & \multicolumn{2}{|c|}{ Phosphate solubilization } \\
\hline & & Positive isolates & Frequency & Positive isolates & Frequency & Positive isolates & Frequency \\
\hline
\end{tabular}

\begin{tabular}{|c|c|c|c|c|c|c|c|}
\hline AGR & 21 & 3 & 0.14 & 1 & 0.05 & 21 & 1 \\
\hline ELD & 25 & 8 & 0.32 & 5 & 0.20 & 17 & 0.68 \\
\hline IRG & 25 & 3 & 0.12 & 4 & 0.16 & 8 & 0.32 \\
\hline CXS & 24 & 5 & 0.21 & 3 & 0.13 & 16 & 0.67 \\
\hline SBO & 25 & 7 & 0.28 & 1 & 0.04 & 11 & 0.44 \\
\hline VAC & 25 & 0 & 0 & 1 & 0.04 & 0 & 0 \\
\hline SGA & 25 & 5 & 0.20 & 0 & 0 & 2 & 0.08 \\
\hline DPE & 24 & 4 & 0.17 & 0 & 0 & 2 & 0.08 \\
\hline RIG & 33 & 0 & 0 & 2 & 0.06 & 21 & 0.64 \\
\hline RIP & 9 & 9 & 1 & 3 & 0.33 & 8 & 0.89 \\
\hline URU & 16 & 15 & 0.94 & 0 & 0 & 0 & 0 \\
\hline Total & 252 & 59 & 0.23 & 20 & 0.08 & 107 & 0.42 \\
\hline
\end{tabular}

(1) Abbreviations: Porto Alegre (AGR), Eldorado do Sul (ELD), Cachoeirinha (IRG), Caxias do Sul (CXS), São Borja (SBO), Vacaria (VAC), São Gabriel (SGA), Dom Pedrito (DPE), Rio Grande (RIG), Rio Pardo (RIP) and Uruguaiana (URU). 
nodules. In this first group, IAA production was much more frequent, found in more than $80 \%$ of the isolates. On the contrary, IAA production was considerably less frequent in rhizobia isolated from white clover nodules, detected in only $15 \%$ of these bacteria. Indoleacetic acid production is frequently pointed out as one of the main mechanisms of plant growth promotion (Biswas et al., 2000a; Khalid et al., 2004; Chi et al., 2005; Lee et al., 2006). However, this positive effect depends on the amount of IAA produced by the bacterium, since an IAA overproduction is considered deleterious to plants (Barazani \& Friedman, 1999; Ahmad et al., 2005; Schlindwein et al., 2008). Similarly to other phytohormones, IAA exerts a stimulatory effect on plant growth within a narrow concentration range only, outside of which the plant is either unresponsive or its growth is inhibited (Biswas et al., 2000b). Barazani \& Friedman (1999) found that deleterious rhizobacteria produced high IAA levels, about $77 \mu \mathrm{mol} \mathrm{L}{ }^{-1}$ after $84 \mathrm{~h}$ of incubation, while a consortia of beneficial rhizobacteria produced much less IAA $\left(16 \mu \mathrm{mol} \mathrm{L}{ }^{-1}\right)$ in the same period.

Based on the analyzed PGPR features, ten isolates were chosen for further evaluation. The isolates AGR3, AGR-7, CXS-12, DPE-12, ELD-15, ELD-18, IRG17, SGA-15, SBO-3, and VAC-12 have different PGPR features (Table 2). These isolates, along with the reference strains SEMIA 222 and SEMIA 235, were genotypically characterized by rep-PCR. The genotypic results were used to construct a dendrogram (Figure 1). Based on the dendrogram, two groups (groups A and B) were formed with a Jaccard similarity coefficient of about $30 \%$. Group A comprised seven isolates. Both reference strains clustered within group $\mathrm{B}$ together with other three isolates. The most similar isolates were ELD-15 and ELD-18 (87 \% similarity), both from the Eldorado do Sul site.

Interestingly, all isolates differ by more than $60 \%$ from the reference strains SEMIA 222 and SEMIA 235.

Table 2. Plant growth-promoting characteristics of selected rhizobial isolates and reference strains

\begin{tabular}{|c|c|c|c|}
\hline \multirow{2}{*}{ Isolate } & \multicolumn{3}{|c|}{ PGPR Trait } \\
\hline & $\begin{array}{c}\text { IAA } \\
\text { production }\end{array}$ & $\begin{array}{c}\text { Siderophore } \\
\text { production }\end{array}$ & $\frac{\text { P }}{\text { Solubilization }}$ \\
\hline AGR-3 & - & + & + \\
\hline AGR-7 & + & - & + \\
\hline CXS-12 & - & + & + \\
\hline DPE-12 & + & - & - \\
\hline ELD-15 & + & + & + \\
\hline ELD-18 & - & - & + \\
\hline IRG-17 & - & + & + \\
\hline SOB-3 & + & + & - \\
\hline SGA-15 & + & - & - \\
\hline VAC-12 & - & - & - \\
\hline SEMIA 222 & + & - & - \\
\hline SEMIA 235 & + & - & - \\
\hline
\end{tabular}

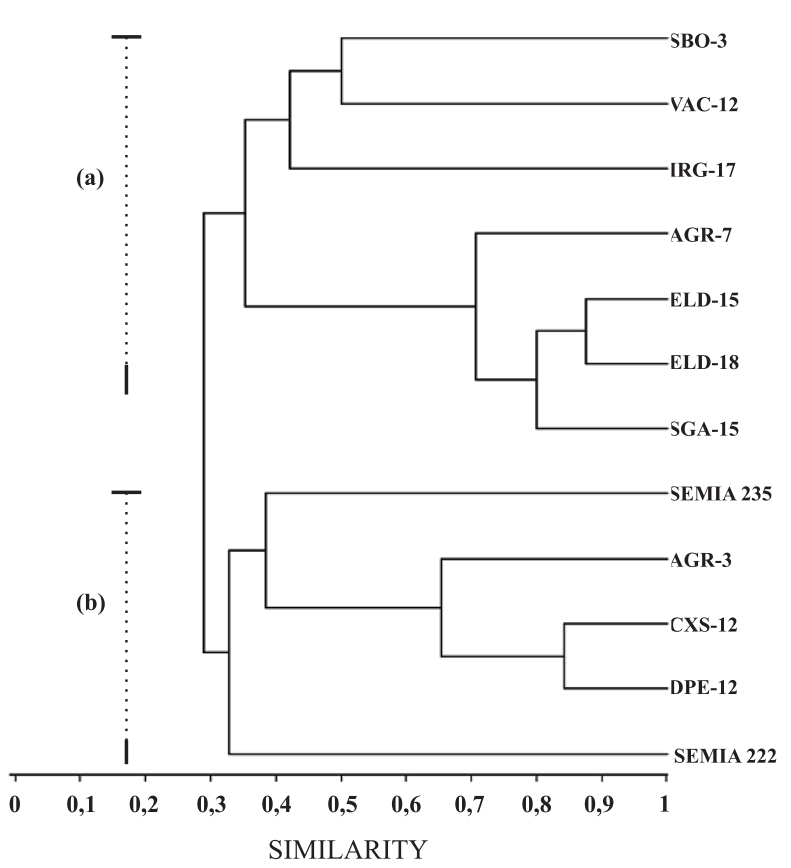

Figure 1. Unweighted pair group mathematical average dendrogram of clover-nodulating rhizobia based on Jaccard's similarity index derived from rep-PCR data.

Similar results were observed in other studies evaluating genetic diversity in soils of Rio Grande do Sul. Vargas et al. (2007) evaluated the genetic diversity of black wattle (Acacia mearnsii) nodulating rhizobia, and found no isolate with a similarity degree to the reference strains of over $73 \%$. In fact, the reference strains were found to be more similar to each other than to any native isolate. Lack of inoculation in black wattle was pointed out as a possible cause for dissimilarity between reference strains and native rhizobia. However, even massive annual inoculation, as practiced in Rio Grande do Sul in soybean crops, does not ensure that reference strains remain in the soil without genetic variation, as observed by Giongo et al. (2008). The authors verified a high level of genetic diversity within soybean bradyrhizobia populations, which showed a similarity degree to the reference strains of less than $50 \%$. It was found that $\mathrm{pH}$ was the main soil property affecting bradyrhizobial diversity.

The ten isolates were tested for antagonism against the phytopathogenic fungus Verticillium sp. In all isolates some level of antagonism against Verticillium sp was observed (Figure 2). Inhibition levels of the isolates CXS-12, AGR-3, ELD-15, VAC-12, and DPE12 were highest. This result is in agreement with findings of Chao (1990) and Antoun et al. (1998), who observed antagonistic action of many rhizobial strains against phytopathogenic fungi, regardless of their symbiotic effectiveness. Hossain \& Mårtensson (2008) also found that some rhizobial strains are able to dissolve fungal mycelium at the initial stage. For this reason, rhizobia may be potentially used as 


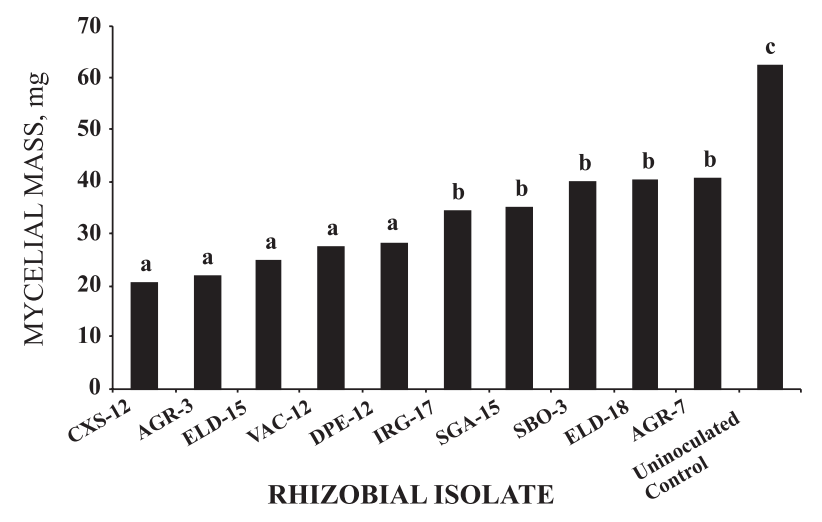

Figure 2. Inhibition of Verticillium sp. mycelial mass production by rhizobial isolates. Means followed by the same letter did not differ significantly at $p=0.05$ (Scott-Knott test).

biological control agents, though they may also be detrimental to beneficial fungi, such as Trichoderma sp. (Chao, 1990).

The two isolates with strongest antagonistic action, CXS-12 and AGR-3, which decreased mycelial growth by about $65 \%$, were also siderophore producers. Siderophore production is considered one of the most important mechanisms for the suppression of phytopathogens due to the competition for iron (Arora et al., 2001). However, two other siderophoreproducing isolates, IRG-17 and SBO-3, proved to have a less pronounced antagonistic action than other nonsiderophore producers. This result may be related to the type of siderophore produced by each isolate. Matthijs et al. (2007) observed that Pseudomonas fluorescens ATCC 17400 produced two siderophores, pyoverdine and thioquinolobactin, with a much more intense antifungal activity of thioquinolobactin than of pyoverdine. However, the media used in this test were not iron-deficient. Under this condition, siderophore is not expected to be produced. Besides, siderophore-negative isolates ELD-15, VAC-12 and DPE-12 were as antagonistic as CXS-12 and AGR-3, indicating that fungal suppression does not depend on siderophore production. Other non-evaluated mechanisms, such as the production of HCN (Bano $\&$ Musarrat, 2004) or of $\beta$-1,3-glucanase, proteases and chitinases (Compant et al., 2005) may have contributed to the decrease of Verticillium sp. growth by rhizobia.

When rhizobia were inoculated in rice seeds, to test their ability to promote germination vigor and seedling growth, positive effects were revealed. In general, the rhizobia isolates were beneficial in some aspect for the plants (Tables 3 and 4). Aside from AGR-7, which always produced results that equaled those of the control, all other isolates improved at least one parameter evaluated. Contrary to observations in other studies (Antoun et al., 1998, Hilali et al., 2001), none of the isolates were found to be deleterious to the plants.

A total of eight isolates increased initial germination rates, four days after sowing (Table 3). In subsequent evaluations, six and ten days after sowing, germination rates were equivalent among treatments. Even though final germination rates were unaffected by rhizobial inoculation, the increase in initial germination rates promoted by those eight isolates led to an associated increase in the germination speed index. Earlier germination in bacterized seeds was also reported by Biswas et al. (2000b), Gupta et al. (2002), Pandey et al. (2005) and Schlindwein et al. (2008), and is an important factor for crop establishment. The increase in seedlings vigor is an important aspect in rice crops, because it may result in earlier seedling emergence, allowing rice seedlings to overcome weed competition (Gibson et al., 2002).

Table 3. Germination percentage during 10 days and germination speed index (GSI) of rice seeds inoculated with R. leguminosarum biovar trifolii isolates

\begin{tabular}{|c|c|c|c|c|}
\hline \multirow{2}{*}{ Isolate } & \multicolumn{4}{|c|}{ Germination $^{(1)}$} \\
\hline & $\mathbf{G}_{4}$ & $\mathbf{G}_{6}$ & $\mathbf{G}_{10}$ & GSI \\
\hline & \multicolumn{4}{|c|}{$\%$} \\
\hline Uninoculated Control & $6.0 \mathrm{~b}$ & 80.5 n.s. & $81.0^{n . s}$ & $17.0 \mathrm{~b}$ \\
\hline AGR-3 & $46.0 \mathrm{a}$ & 78.5 & 81.5 & $22.3 \mathrm{a}$ \\
\hline AGR-7 & $23.0 \mathrm{~b}$ & 74.5 & 79.0 & $18.6 \mathrm{~b}$ \\
\hline CXS-12 & $35.5 \mathrm{a}$ & 79.0 & 82.0 & $21.0 \mathrm{a}$ \\
\hline DPE-12 & $42.5 \mathrm{a}$ & 77.0 & 81.0 & $21.6 \mathrm{a}$ \\
\hline ELD-15 & $56.0 \mathrm{a}$ & 81.5 & 85.5 & $24.3 \mathrm{a}$ \\
\hline ELD-18 & $48.0 \mathrm{a}$ & 70.5 & 78.0 & $21.6 \mathrm{a}$ \\
\hline IRG-17 & $57.5 \mathrm{a}$ & 80.0 & 82.5 & $24.0 \mathrm{a}$ \\
\hline SBO-3 & $21.0 \mathrm{~b}$ & 75.5 & 79.0 & $18.4 \mathrm{~b}$ \\
\hline SGA-15 & $46.0 \mathrm{a}$ & 74.5 & 78.5 & $21.6 \mathrm{a}$ \\
\hline VAC-12 & $47.0 \mathrm{a}$ & 76.5 & 80.5 & $22.1 \mathrm{a}$ \\
\hline
\end{tabular}

\footnotetext{
${ }^{(1)} \mathrm{G}_{4}, \mathrm{G}_{6}$ and $\mathrm{G}_{10}=4,5$ and 10 days after sowing, respectively. ${ }^{\text {n.s. }}$ Non-significant. Means in the same column followed by the same letter did not differ significantly at $\mathrm{p}=0.05$ (Scott-Knott test).
} 
Table 4. Root and shoot length and dry matter of rice seedlings inoculated with R. leguminosarum biovar trifolii isolates

\begin{tabular}{|c|c|c|c|}
\hline Isolate & Root length & Shoot length & Seedling weight \\
\hline & $\longrightarrow$ & - & $\mathrm{mg}$ \\
\hline Uninoculated Control & $40.1 \mathrm{c}$ & $28.3 \mathrm{e}$ & $30.4 \mathrm{~b}$ \\
\hline AGR-3 & $93.6 \mathrm{a}$ & $41.1 \mathrm{c}$ & $38.0 \mathrm{~b}$ \\
\hline AGR-7 & $34.6 \mathrm{c}$ & $25.4 \mathrm{e}$ & $33.4 \mathrm{~b}$ \\
\hline CXS-12 & $22.4 \mathrm{~d}$ & $42.3 \mathrm{c}$ & $35.0 \mathrm{~b}$ \\
\hline DPE-12 & $36.7 \mathrm{c}$ & $39.2 \mathrm{c}$ & $33.8 \mathrm{~b}$ \\
\hline ELD-15 & $46.6 \mathrm{~b}$ & $43.7 \mathrm{c}$ & $36.6 \mathrm{~b}$ \\
\hline ELD-18 & $54.4 \mathrm{~b}$ & $59.4 \mathrm{a}$ & $47.4 \mathrm{a}$ \\
\hline IRG-17 & $44.0 \mathrm{~b}$ & $36.1 \mathrm{~d}$ & $41.1 \mathrm{a}$ \\
\hline SBO-3 & $45.0 \mathrm{~b}$ & $51.3 \mathrm{~b}$ & $48.0 \mathrm{a}$ \\
\hline SGA-15 & $37.5 \mathrm{c}$ & $40.2 \mathrm{c}$ & $33.6 \mathrm{~b}$ \\
\hline VAC-12 & $34.0 \mathrm{c}$ & $46.8 \mathrm{c}$ & $34.6 \mathrm{~b}$ \\
\hline
\end{tabular}

Means in the same column followed by the same letter did not differ significantly at $\mathrm{p}=0.05$ (Scott-Knott test).

Regarding the biometric parameters, inoculation with rhizobia induced changes in root and shoot length and seedling weight, compared to uninoculated control (Table 4). The isolate CXS-12 decreased root length, while five other isolates (AGR-3, ELD-15, ELD-18, IRG-17, and SBO-15) increased the trait. The root length of seedlings inoculated with AGR-3 was more than twice as long as of the uninoculated control. All isolates, except AGR-7, increased shoot length to some degree. The greatest increase of shoot length was observed in the isolates ELD-18, followed by SBO-3. These two isolates, along with IRG-17, also increased seedling weight.

Deleterious bacteria are common among rhizobacteria (Schippers et al., 1990; Barazani \& Friedman, 1999), including rhizobia (Antoun et al., 1998; Hilali et al., 2001). However, in this study, no clearly deleterious isolate was detected. With the exception of isolate AGR-7, which was not different from the uninoculated control, all isolates improved at least one analyzed parameter, including VAC-12, where no PGPR trait was detected. Isolate CXS-12, for instance, reduced root length, but increased seedling vigor and shoot length.

\section{CONCLUSIONS}

1. Phosphate solubilization was the most common PGPR trait found in clover-nodulating rhizobial isolates, while siderophore production was the rarest. The PGPR trait frequency was related to the sampling sites and host plant species.

2. Clover-nodulating rhizobia are potential biological control agents, as indicated by the inhibition of Verticillium sp. mycelial growth.
3. Clover rhizobia can promote early rice growth. Isolate ELD-18 increased root and shoot length and dry weight of rice seedlings, besides increasing the germination speed index of rice seeds.

\section{ACKNOWLEDGEMENTS}

This research was supported by the International Foundation for Science (IFS), Stockholm, Sweden (grant C/3820-1) and the Fundação Estadual de Amparo à Pesquisa (FAPERGS), Porto Alegre, Brazil (grant 05/2146.9).

\section{LITERATURE CITED}

AHMAD, F.; AHMAD, I. \& KHAN, M.S. Screening of freeliving rhizospheric bacteria for their multiple plant growth-promoting activities. Microbiol. Res., 163:173-181, 2008.

AHMAD, F.; AHMAD, I. \& KHAN, M.S. Indole acetic acid production by the indigenous isolates of Azotobacter and fluorescent Pseudomonas in the presence and absence of tryptophan. Turk. J. Biol., 29:29-34, 2005.

ALAMI, Y.; ACHOUAK, W.; MAROL, C. \& HEULIN, T. Rhizosphere soil aggregation and plant growth promotion of sunflowers by an exopolysaccharide-producing Rhizobium sp. strain isolated from sunflower roots. Appl. Environ. Microbiol., 66:3393-3398, 2000.

ANTOUN, H.; BEAUCHAMP, J.; GOUSSARD, N.; CHABOT, R. \& LALANDE, R. Potential of Rhizobium and Bradyrhizobium species as plant growth-promoting rhizobacteria on non-legumes: Effect on radishes (Raphanus sativus L.). Plant Soil, 204:57-67, 1998. 
ARORA, N.K.; KANG, S.C. \& MAHESHWARI, D.K. Isolation of siderophore-producing strains of Rhizobium meliloti and their biocontrol potential against Macrophomina phaseolina that causes charcoal rot of groundnut. Curr. Sci., 81:673-677, 2001

ASGHAR, H.N.; ZAHIR, Z.A.; ARSHAD, M. \& KHALIQ, A. Relationship between in vitro production of auxins by rhizobacteria and their growth-promoting activities in Brassica juncea L. Biol. Fert. Soils, 35:231-237, 2002.

BANO, N. \& MUSARRAT, J. Characterization of a new Pseudomonas aeruginosa strain NJ-15 as a potential biocontrol agent. Curr. Microbiol., 46:324-328, 2004.

BARAZANI, O. \& FRIEDMAN, J. Is IAA the major root growth factor secreted from plant-growth-mediating bacteria? J. Chem. Ecol., 25:2397-2406, 1999.

BASHAN, Y. Inoculants of plant growth-promoting bacteria for use in agriculture. Biotechnol. Adv., 16:729-770, 1998.

BERTRAND, H.; NALIN, R.; BALLY, R. \& CLEYET-MAREL, J.C. Isolation and identification of the most efficient plant growth-promoting bacteria associated with canola (Brassica napus). Biol. Fert. Soils, 33:152-156, 2001.

BISWAS, J.C.; LADHA J.K. \& DAZZO, F.B. Rhizobia inoculation improves nutrient uptake and growth of lowland rice. Soil Sci. Soc. Am. J., 64:1644-1650, 2000a.

BISWAS, J.C.; LADHA J.K.; DAZZO F.B.; YANNI, Y.G. \& ROLFE, B.G. Rhizobial inoculation influences seedling vigor and yield of rice. Agron. J., 92:880-886, 2000b.

CHAO, W.L. Antagonistic activity of Rhizobium spp. against beneficial and plant pathogenic fungi. Lett. Appl. Microbiol., 10:213-215, 1990.

CHI, F.; SHEN, S.H.; CHENG, H.P.; JING, Y.X.; YANNI, Y.G. \& DAZZO, F.B. Ascending migration of endophytic rhizobia from roots to leaves, inside rice plants and assessment of benefits to rice growth physiology. Appl. Environ. Microbiol., 71:7271-7278, 2005.

COMPANT, S.; DUFFY, B.; NOWAK, J.; CLEMENT, C. \& BARKA, E.A. Use of plant growth-promoting bacteria for biocontrol of plant diseases: Principles, mechanisms of action, and future prospects. Appl. Environ. Microbiol., 71:4951-4959, 2005.

DE BRUIJN, F.J. Use of repetitive (repetitive extragenic palindromic and enterobacterial repetitive intergeneric consensus) sequences and the polymerase chain reaction to fingerprint the genomes of Rhizobium meliloti isolates and other soil bacteria. Appl. Environ. Microbiol., 58:2180 $2187,1992$.

FREITAS, S.S. \& VILDOSO, C.I.A. Rhizobacteria and growth promotion of citrus plants. R. Bras. Ci. Solo, 28:987-994, 2004.

GARCÍA, J.A.L.; PROBANZA, A.; RAMOS, B.; BARRIUSO, J. \& MAÑERO, F.J.G. Effects of inoculation with plant growth-promoting rhizobacteria (PGPRs) and Sinorhizobium fredii on biological nitrogen fixation, nodulation and growth of Glycine $\max$ cv. Osumi. Plant Soil, 267:143-153, 2004.
GIBSON, K.D.; FISCHER, A.J.; FOIN, T.C. \& HILL, J.E. Implications of delayed Echinochloa spp. germination and duration of competition for integrated weed management in water-seeded rice. Weed. Res., 42:351-358, 2002.

GIONGO, A.; AMBROSINI, A.; VARGAS, L.K.; FREIRE, J.R.J.; BODANESE-ZANETTINI, M.H. \& PASSAGLIA, L.M.P. Evaluation of genetic diversity of bradyrhizobia strains nodulating soybean [Glycine $\max (\mathrm{L}$.) Merrill] isolated from South Brazilian fields. Appl. Soil Ecol., 38:261-269, 2008 .

GRAY, E.J. \& SMITH, D.L. Intracellular and extracellular PGPR: Commonalities and distinctions in the plantbacterium signaling processes. Soil Biol. Biochem., 37:395$412,2005$.

GUPTA, C.; DUBEY, R. \& MAHESHWARI, D. Plant growth enhancement and suppression of Macrophomina phaseolina causing charcoal rot of peanut by fluorescent Pseudomonas. Biol. Fert. Soils, 35:399-405, 2002.

HILALI, A.; PREVOST, D.; BROUGHTON, W.J. \& ANTOUN, H. Effects of inoculation with Rhizobium leguminosarum biovar trifolii on wheat cultivated in clover crop rotation agricultural soil in Morocco. Can. J. Microbiol., 47:590593,2001

HOSSAIN, S. \& MÅRTEnsson, A. Potential use of Rhizobium spp. to improve fitness of non-nitrogen-fixing plants. Acta Agric. Scand. B, 58:352-358, 2008.

INTERNATIONAL RULES FOR SEED TESTING - ISTA. Seed science and technology. Zürich, 1996. 335p.

JOO, G.J.; KIM, Y.M.; KIM, J.T.; RHEE, I.; KIM, J. \& LEE, I. Gibberellins-producing rhizobacteria increase endogenous gibberellins content and promote growth of red peppers. J. Microbiol., 43:510-515, 2005.

KHALID, A.; ARSHAD, M. \& ZAHIR, Z.A. Screening plant growth-promoting rhizobacteria for improving growth and yield of wheat. J. Appl. Microbiol., 96:473-480, 2004.

KLOEPPER, J.W.; SCROTH, M.N. \& MILLER, W. Effects of rhizosphere colonization by plant growth-promoting rhizobacteria on potato plant development and yield. Ecol. Epidemiol., 70:1078-1082, 1980.

LEE, H.S.; MADHAIYAN, M.; KIM, C.W.; CHOI, S.J.; CHUNG, K.Y. \& SA, T.M. Physiological enhancement of early growth of rice seedlings (Oryza sativa L.) by production of phytohormone of N2-fixing methylotrophic isolates. Biol. Fert. Soils, 42:402-408, 2006.

MAGUIRE, J.D. Speed of germination - aid in selection for seedling emergence and vigor. Crop. Sci., 2:176-177, 1962.

MATTHIJS, S.; TEHRANI, K.A.; LAUS, G.; JACKSON, W.; COOPER, R.M. \& CORNELIS, P. Thioquinolobactin, a Pseudomonas siderophore with antifungal and antiPythium activity. Environ. Microbiol., 9:425-434, 2007.

NOEL, T.C.; SHENG, C.; YOST, C.K.; PHARIS, R.P. \& HYNES, M.F. Rhizobium leguminosarum as a plant growthpromoting rhizobacterium: Direct growth promotion of canola and lettuce. Can. J. Microbiol., 42:279-283, 1996. 
PANDEY, P.; KANG, S.; GUPTA, C. \& MAHESHWARI, D. Rhizosphere competent Pseudomonas aeruginosa GRC1 produces characteristic siderophore and enhances growth of Indian mustard (Brassica campestris). Curr. Microbiol., 51:303-309, 2005.

RODRIGUEZ, H. \& FRAGA, R. Phosphate solubilizing bacteria and their role in plant growth promotion. Biotecnol. Adv., 17:319-339, 1999.

SCHIPPERS, B.; BAKKER, A.W.; BAKKER, P.A.H.M. \& van PEER, R. Beneficial and deleterious effects of HCN producing pseudomonads on rhizosphere interactions. Plant Soil, 129:75-83, 1990

SCHLINDWEIN, G.; VARGAS, L.K.; LISBOA, B.B.; AZAMBUJA, A.C.; GRANADA, C.E.; GABIATTI, N.C.; PRATES, F. \& STUMPF, R. Influência da inoculação de rizóbios sobre a germinação e o vigor de plântulas de alface. Ci. Rural, 38:658-664, 2008.

SCHWYN, B. \& NEILANDS, J. Universal chemical assay for the detection and determination of siderophores. Anal. Biochem., 160:47-56, 1987.

SOMASEGARAM, P. \& HOBEN, M.J. Handbook for Rhizobia: Methods in legume-Rhizobium technology. New York, Springer-Verlag, 1994. Hawaii, NIFTAL, 1985. 450p.

SOMMERS, E. \& VANDERLEYDEN, J. Rhizosphere bacterial signaling: A love parade beneath our feet. Crit. Rev. Microbiol., 30:205-240, 2004.
SOTTERO, A.N.; FREITAS, S.D.S.; MARCHI, A.; MELO, T.D. \& TRANI, P.E. Rhizobacteria and lettuce: Root colonization, plant growth promotion and biological control. R. Bras. Ci. Solo, 30:225-234, 2006.

SYLVESTER-BRADLEY, R.; ASAKAWA, N.; LA TORRACA, S.; MAGALHÃES, F.M.M.; OLIVEIRA, L. \& PEREIRA, R.M. Levantamento quantitativo de microrganismos solubilizadores de fosfatos na rizosfera de gramíneas e leguminosas forrageiras na Amazônia. Acta Amaz., 12:15$22,1982$.

VARGAS, L.K.; LISBOA, B.B.; SCHOLLES, D.; SILVEIRA, J.R.P.; JUNG, G.C.; GRANADA, C.E.; NEVES, A.G.; BRAGA, M.M. \& NEGREIROS, T.A. Diversidade genética e eficiência simbiótica de rizóbios noduladores de acácianegra de solos do Rio Grande do Sul. R. Bras. Ci. Solo, 31:647-654, 2007.

VERSALOVIC, J.; SCHNEIDER, M.; BRUIJN, F.J.D. \& LUPSKI., J.R. Genomic fingerprinting of bacteria using repetitive sequence-based polymerase chain reaction. Meth. Molec. Cell Biol., 5:25-40, 1994.

YANNI, Y.G.; RIZK, Y.; ABD-EL, F.F.K.; SQUARTINI, A.; CORICH, V.; GIACOMINI, A.; DE BRUIJN, F.; RADEMAKER, J.; MAYA, J.F.; OSTROM, P.; VEJA, H.M.; HOLLINGSWORTH, R.I.; MARTINEZ, E.M.; MATEOS, P.; VELAZQUEZ, E.; WOPEREIS, J.; TRIPLETT, E.; UMALI, G.M.; ANARNA, J.A.; ROLFE, B.G.; LADHA, J.K.; HILL, J.; MUJOO, R.; NG, P.K. \& DAZZO, F.B. The beneficial plant growth-promoting association of Rhizobium leguminosarum bv. trifolii with rice roots. Aust. J. Biol. Sci., 28:845-870, 2001. 